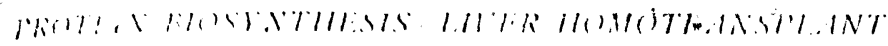

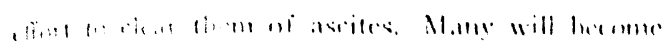

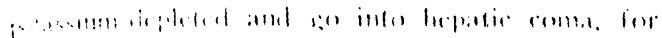

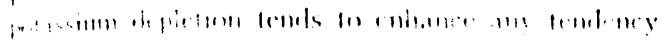

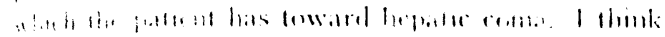

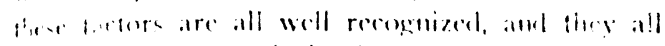

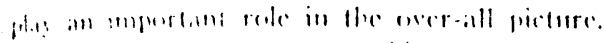

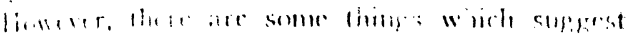

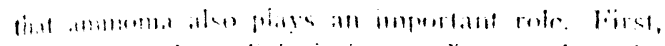

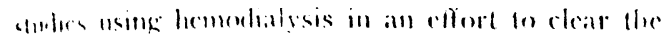
lienal of abmonia has resulted in transitory improsenents; similarly, the experiences with arginine anl kntanic acicl, allhough they are controversial, nenefluclese are predicated on their role in handling

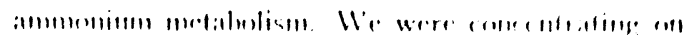

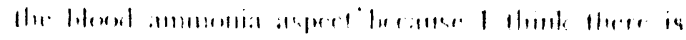

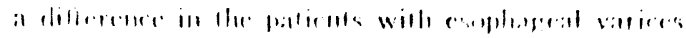

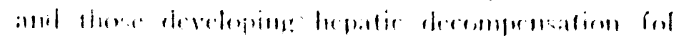

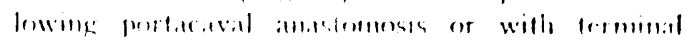

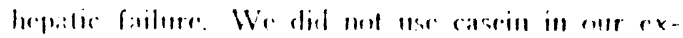
periments lecathe we trierl to kecp it as relese as possuble to the clinical sibation -an pationt with beerling varices. We, lherefore, elected to use while blood for the production of ammonium intoxication. Experimentally, we have used other protein sulstances and fol:nd that they will also produce liyperammonium levels.

bihlish.
\end{abstract}

- restirce lhat ileiwhere al rins

continue mates in rathepatic erer sect dintra-

pse as the ammonis Iresings: rested in eririzentai

( )iar re. sented by

wht in line heir momn andition (O) : cont. nations of rinelly loul sperinoult ila nase the laties are the torich Cintire tind ore wase

a Miris: 1 wiris's armativ Aicrome than cimply inik incic is ammonia m part of tio i1 armonatia is well ited in :ain ana nat int is an! intas 1: atcente ard lerer in: i)iuril) in :

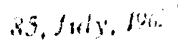

\section{Hepatic Function After Canine Liver} Transplantation

GHI C KIKK.IL W.D.: MARK H. ITTTLEJOHN, M.D.: RICHARD K. WULIAMS, M.D.:

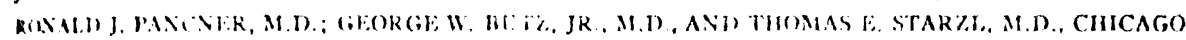

Ifomotranspinted canine livers can survise in recipient logs for as iong as 3 werks."inl Evaluation of liver function and wher lissue metabolism can be male during this time. Studies of this kind may iead to a fxeller umlerstanding of the homesrat rejertion nechanism.

i'revious histological and biocherimeal sturlin in logs followin: total homotranspliantalinen of the liver have shown a marked frubletente collubar response in the organs

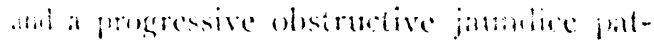

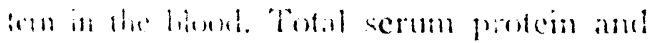

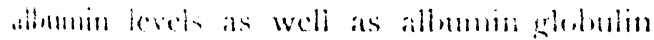

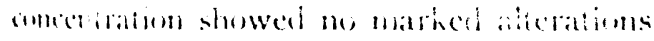
wheminced by ordinary baboratoy methwh." When paper ciectrophoretic analyses wroe buse, is fall in albumin and a rise in a. givinim were most chanderistic. ${ }^{10}$

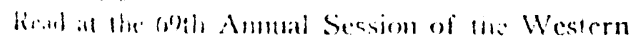

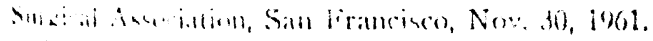

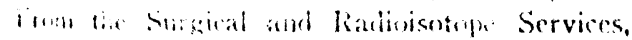

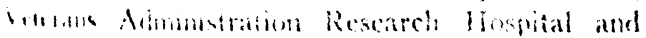
Sullwwem Iniversity Medical School.

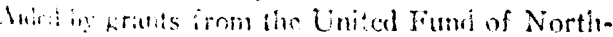

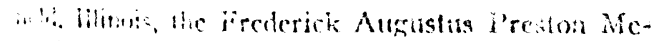

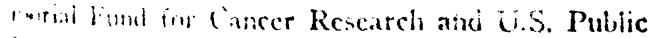
In wibl Gents A.5486 and A.3176.

Aintritlat.
The avaliability of rarlioisotopic techniques for studyiner plasma protein metabolism prompted tive present sturly with 2 objectives in mind: (1) to determine the rate at which the homotransplanted liver synthesizes individual plasma proteins carries out other liver functions, and (2) to determine if there is an alteration of plasma protein synthesis relatel to the homograft rejection phenomenon.

\section{Methods}

The following bischemical stulies were dome be fore and afres total liver lemostransplantation in

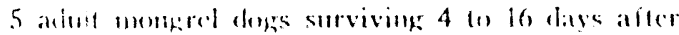
transplant. Bingullesis rates of mucoprotein, fi-

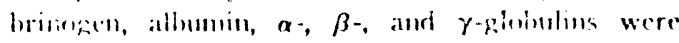
determined using the rate of incorporation of a rationetive labeled amine arid as an index of frofein symbese. The following terhniques were usci as morlifind after Armstrong and associates.' Barle atimal was injecteri with 250 pe of $S^{*}$ methionine, and erial samples of plasma and serum were drawn over a 2.theur periol. The serum proteins of each sample were ferst separated by paper block elertro phoresis into albumin, $\alpha_{1}-, \alpha_{2}, \beta-$, and $\gamma$-giolubins.

The radioactivity of cacil of the alove fractions was then measured in a thin window, gas flow Geiger-Muller cotinter in the form of a precipitate of each iraction as previousiy described." All re- 


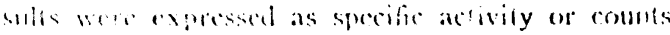

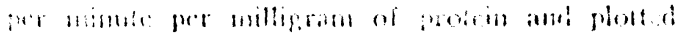

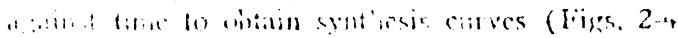

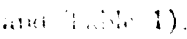

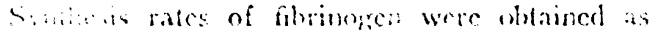

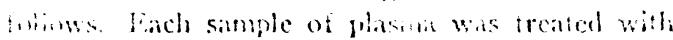
bovine thromsin to form a fibrin clot which wes andere ior radienctivity by a morification of the metherd of Jacobsson as previou'y acionted." The fibitio cot is dissolved and reprecipiated, and ratioactivity per milligram of fibrin is determincel ir a fas fow scintillation comter.

Syathesis curves of the inucoprotein fraction were deternind using a molification of the method of dic ha Meurga and associaics as foi'ow s. The pro. teins of $2 \mathrm{ec}$. of each serum sasuple were precipitatcd with perchloric acisl, baving the acrlic mucoproten in solution. These muronrotems were then precipitated with phosplotiongstic arid and their concentration detcrmines turbidimetrically. The suspension was centrifiget, fitcred, and the inceivitate oxidized to a line fowler whicin was then suremel in a liquid metime as described by

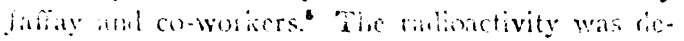

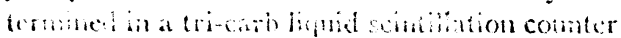

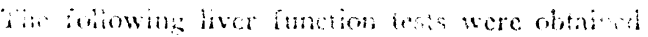

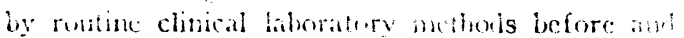
aiter anplate untia the deain o. the animal: se-

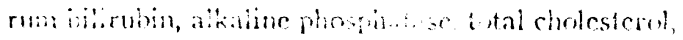

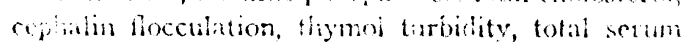
pre in, and scrum albumin

The donor anmal, were struic 4 to 6 wess prior to iranspiantation to alinw for disippcaratice of areinctivity from the tissies of the donor animals. Total transplantation of the liver was then cone as previously reportiel." Silenactomics were not reriurmed except in one (ing (No. 1); in this animal splenectomy marle it rasier to areomplisis

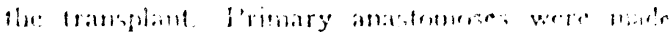

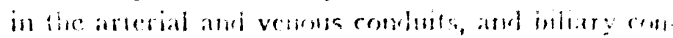

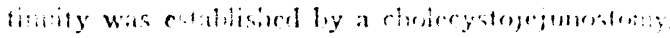

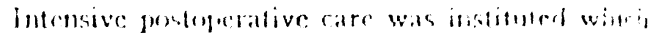

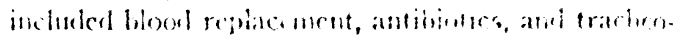

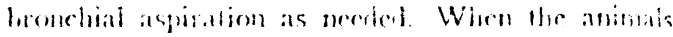
were stable, eating, and repuired no iurther bloxi replacenent, they were injected with $250 \mu \mathrm{c}$ of $\mathrm{S}^{\mathrm{m}}$ methionine on the third to fourth day after the transplant. Serial samples of serum and plasma were again drawn for the next 24 hours and analyzed ior adinativity in the same manner. Baseline sanules of serum and plasma were andyzed for residual rarlioactivily before the injection of ihe $S^{a s}$ methionine, and these values were subtracted from cach sub.equent determination. The amount of residual radioactivity was in all instances prictically negligible. Routine liver function tests were done every 1 or 2 days until the death of the animals.

\section{Results}

Survialal and Clinicopathological Obseria(ions. - The 5 doess stivited survived from is to 16 days for a mean survival time of 9.2 days. The rog which survied thass (No. 5) was fotand deari in his cage on the fifth post-transpiant day after compictiner tic 24 hour synthesis study. Postmortem examination revealed ail anastomoses to be intuci, bit tiie liver was engorged. The exact cause of death was not evident from the gross inspection of the organs. The other 4 animals survived $7,8, i 1$, and 16 days and presumably

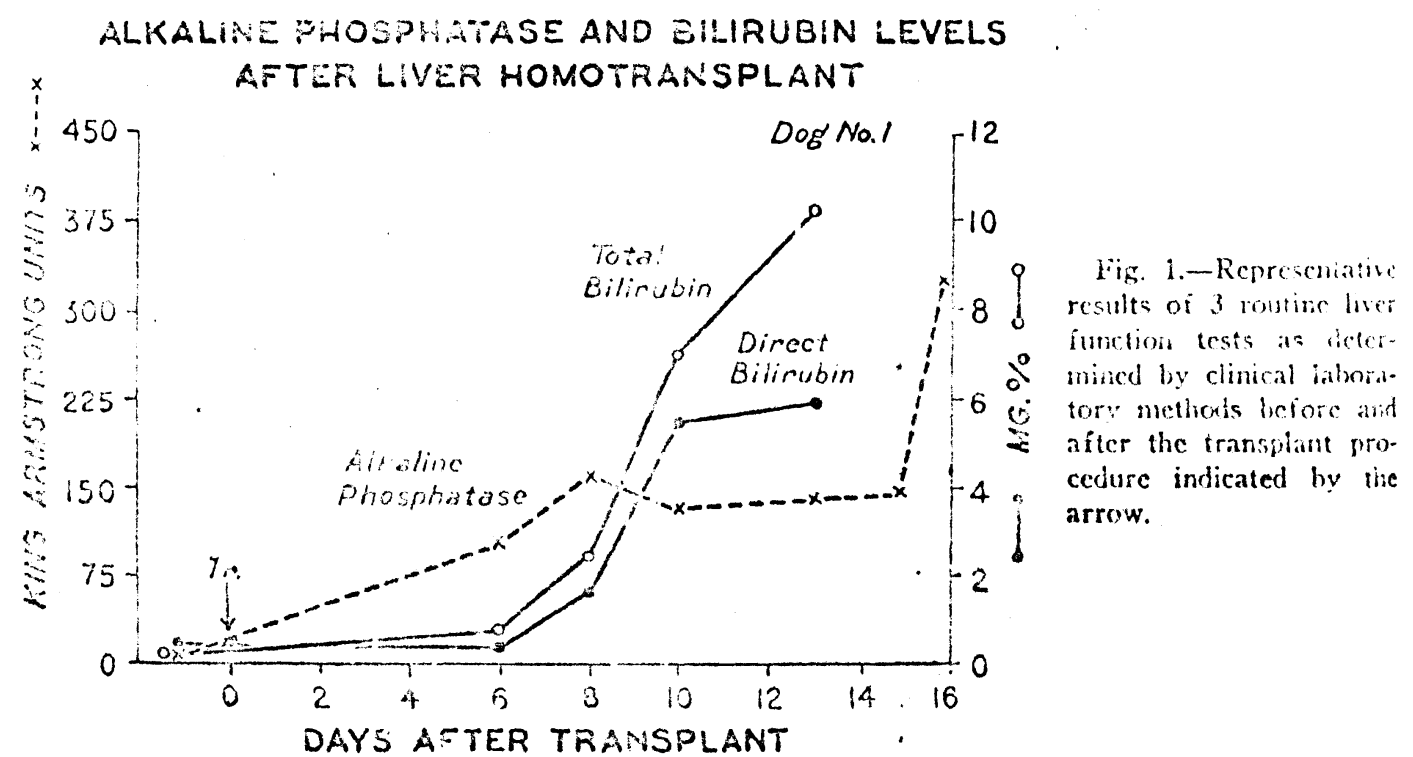

diced of $t$

The rigas

dirseces

decriber

oi livertr.

esecially

mer appe:

gesterl liv

Clinical

aíter reco nous fluir the first 1 sugar, brs given. $\mathrm{Ph}$. 6 days. anorectic, to lic quie

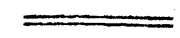




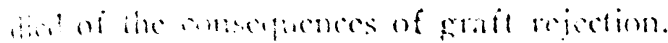

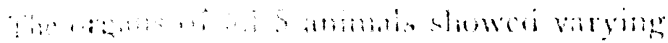

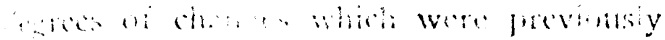

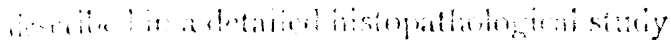

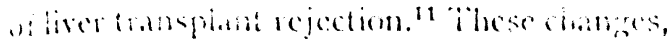
cyecinty at the liver, were those of a mut.

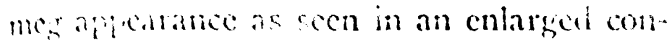
acsitod liver.

Clinically the animais behneded nomaliy afier recovery from the anesthetic. Inurave-

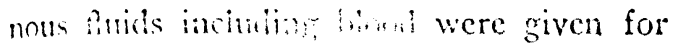

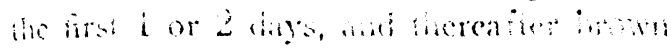
susa, bend, milk, and maple symp were Given. Physical activity was nomai fo: 3 in 6 days. Thereatier the anima!s becunc anorectic, lethargic, feverish, and pieforact it ie quictly in their cages. Intrave, wh th- cose and soline were given to stipplenent

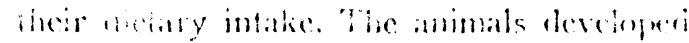
lewhre ous and becane jamblicerl. Three of the 5 mintis becanie omatose 1224 hours

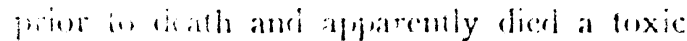

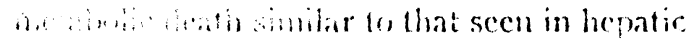
comai un mencmia.

Biosn'nthesis of Plasma P'rotcins.-In all 5 animuls there was evidence of plasma protein synthesis on the fourth day after transplant. These results are summarized in the

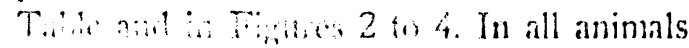
fibinogen was most rively synthesized and albuabia the siowest, whether it was before or afier transplant. This has previously been confirmea in other studies in normal dogs. Fibrinoren is, thus, a labile protein and is 
lik. 2.-Gaimma-globulin s.nthesis curves 'efore and on the fourth day acier total homotransplantation of the liver.

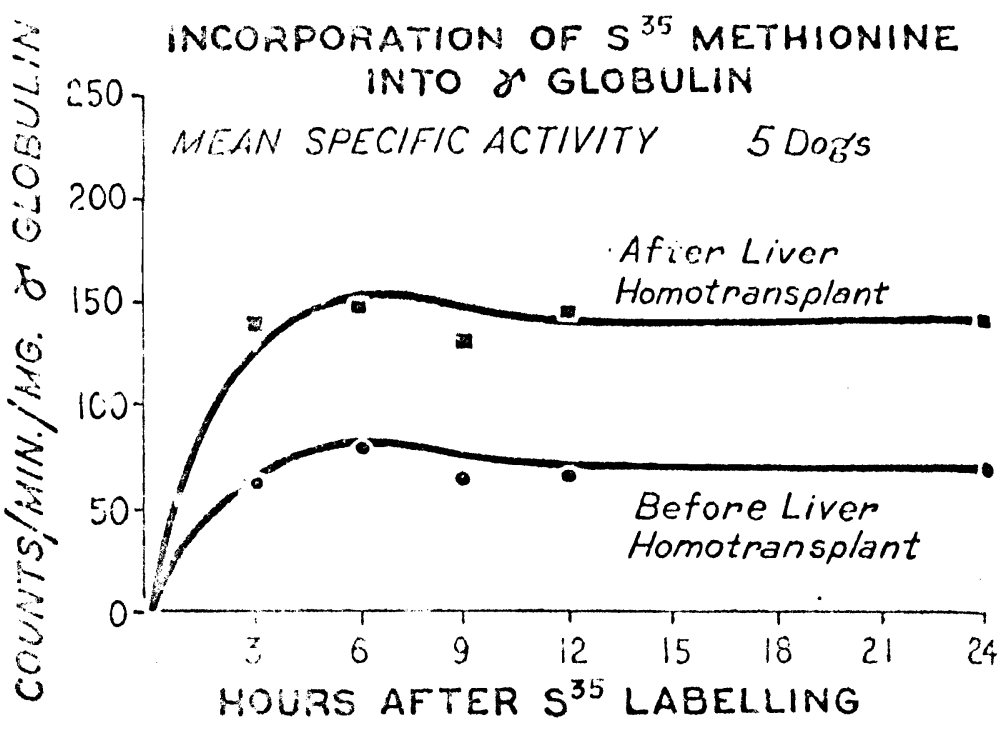

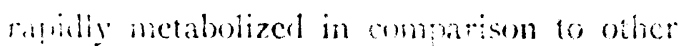
pisisian protems.

A comparison of formation rates helowe

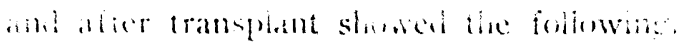

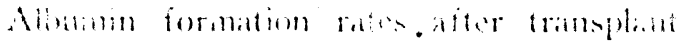
were mereased in 3 doge sesentialiy mi-

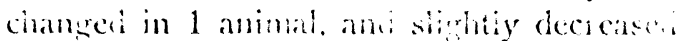
in awther. Fibrinogen sutiosis was increaserl in 3 of 4 anmais an i markedly recreased in the othere. There diflerences ate

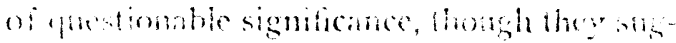
sere an wereall increase in synthesis in mo ammods. The marked decrease in fibrimesen

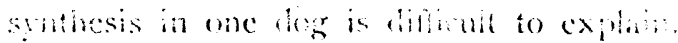

The absence of the spleen is probably not a factor, since fibrinogen is wholly hepati: in origin.

The syothesis of $n_{1}$-grolulin was increased in all mimals, but in one the incrass was small. in 2 animals a lwofold increase wa seen. lieta-globulins showed increases in if of 5 animals. la one animal a small decrease was noted. These differences are of borderline significance in view of the small mmaber of animals stulied.

Mosi significant increases were noted in the formation rates of the $\alpha_{2}$-and $\gamma$-ghobulins. These fractions showed a marked increase

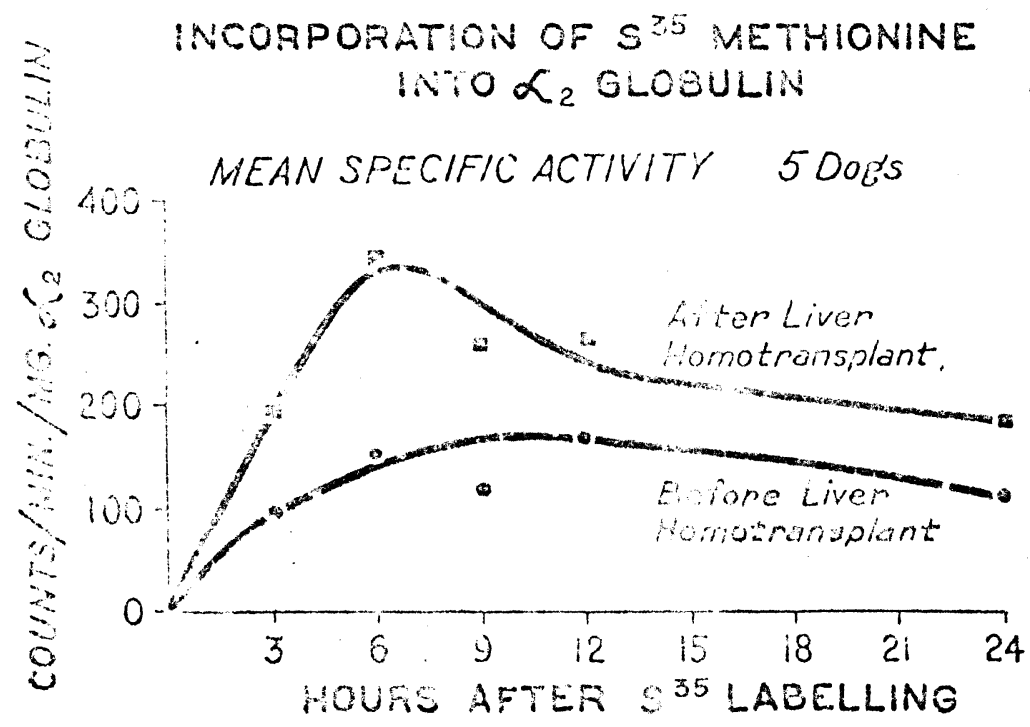

176
Fi, 3. -Alphine-ginbuin symbesis curve before ani on the fourth day afler total homotransplamtasing of the liver.

V.1. $85,1 \mathrm{w}, 100$.

Nutural ef a

rie 5nimations o aind alloum clinical lair wis Note tl dianiges in untii the a deatis. The issate the plant and protcin syn

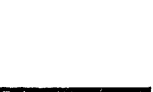




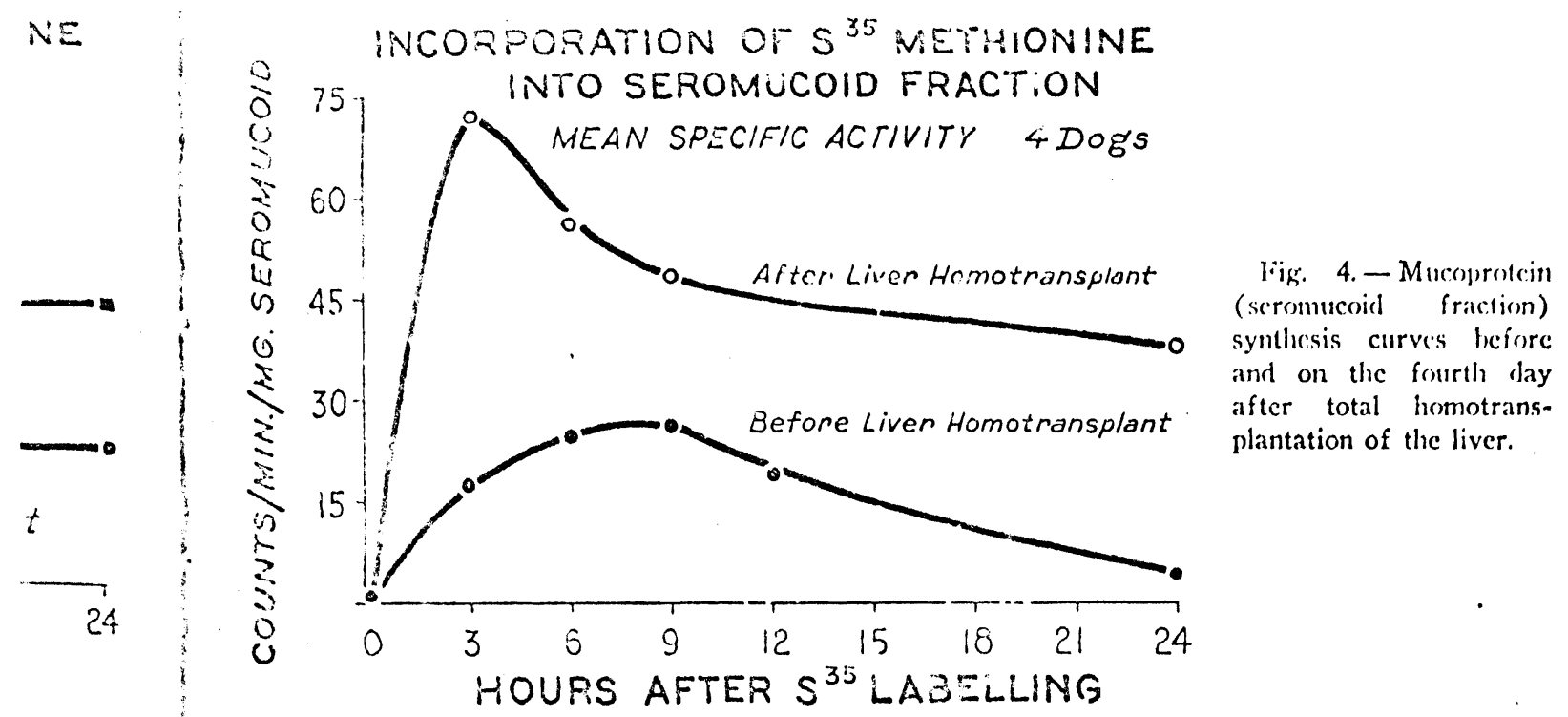

y not a

in purlution in all 5 dogs. The racan incrates were over 2 times normal in both facions. In addition, the peak syathesis of a-ghbulin as noted on the 24-hom syntivesis curbes (I.j. 3) was andined at 6 hours after iransplant as compared to 12 howes in the nomai. Coincident with the increased overall formation rate of the $\alpha_{2}$-globuini, a marked increase in synthesis of mucoproteins was noted. An caricr maximum synthesis was also seen with this iraction after trans- plantation as compared to the pretransplant curve. Thus the highest specific activity after tansplumi was seen at 3 hours in comparison to 9 hours in the normal (Fig. 4).

Sirer fiunction iests. - A progressive rise in alkaline phosphatasc and total and dircet bilirubin was noted in 4 animals. The fifth dog survived only long enough for the protein syathesis study ( Dog 5). The alkaline phrosponatase rose earlicr than the bilirubin levels in 3 rlogs. Both increased simulane- ateris bulins. ncrease

Hobulin iorc initi ly aiter iantation

\section{ALEUMIR. AND TOTAL PROTEIN LEVELS AFTER LIVER HOMOTAAMSPLANT}

Dog No.1

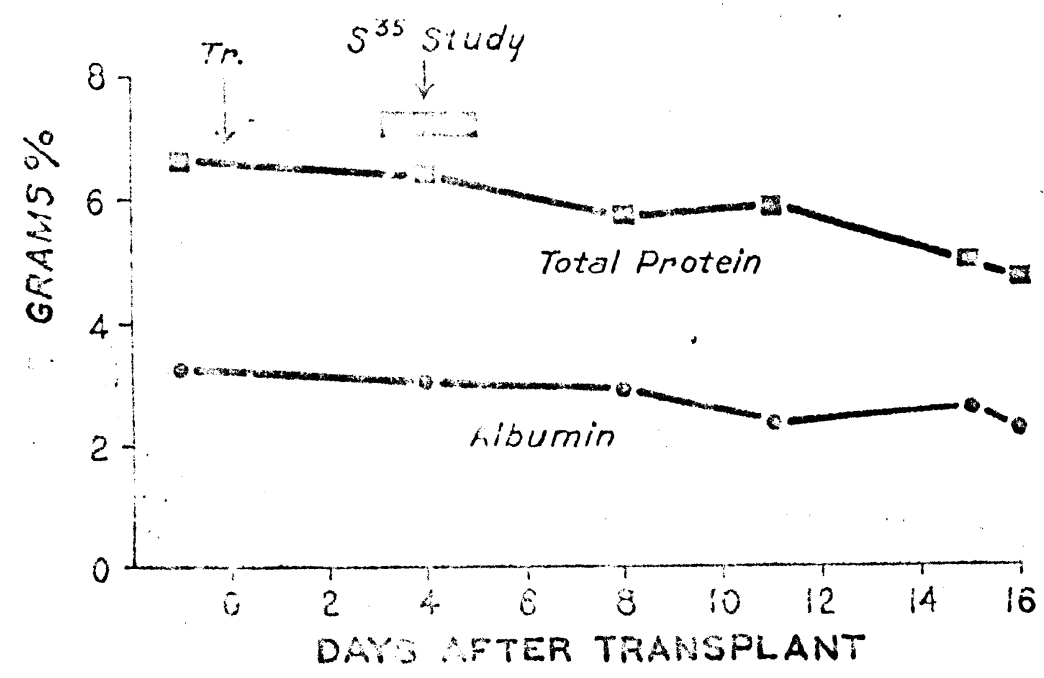


only in the fouth animal. These tinings are consistent with those reported in prerious sturlies. ${ }^{10.11}$ Total cholesterol rose in 3 dings. In 2 of these 3 animists there was a twofold increase. Afier an initial rise in one animal (i) 1 ), there was a marked drop in totil chinesterol 2 days before the drath of the amimal. Thymol turbidity increased in small amontuts over baseline values in 2 anmais and showed no significant cianges in the thirel dog. Cephalin flocculation tests were the lcast consistent of all, ranging fron $1+$ to 3 - - at various times after transplant. Dog 1 revenied a $4+$ reaction on the tenth pustmansplant day but varied fiom $1+$ to $2+$ before and after this.

Tolal protcin and scrum atbanin levels, as determined by routine elinical laboratory methods, were not significantly altered except that a drop occurred betore death. Thus, the tota! protein ievels in Lo, I varied from (.3) to $0.0 \mathrm{gm}$. So up to the 11 h post-transfhat hay. On we 15th and lolin day just

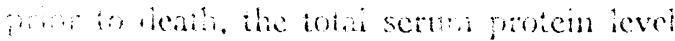

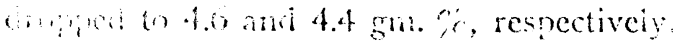

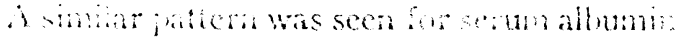

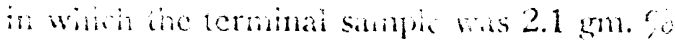

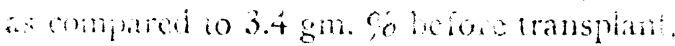

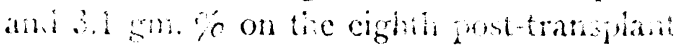
diay (itg 5)

Qualihtiot changes in serwa proteins in

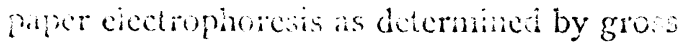
siaming were not seen in ove: $5 j$ determirations. Specific nobility measurements, however, were not determined.

\section{Comaení}

The histological changes in the tissues of the lost following total howolronspiantatim of the comine liver have ben decribed

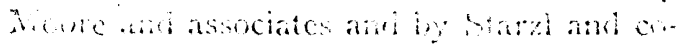

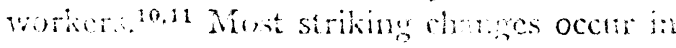
the whens of the retictiocmotrina systom. nenewar has how that the size of the

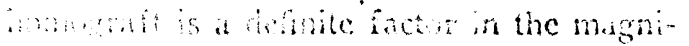
ate wh the acsponse dicted when shin mastintol" The harer the san graft the nore accowated the rejections erponse. $A$. Mowle and associates have hadeated, the bive: is the largest homogenous mass of antigenic coils witich can be transplanted in mammals. ${ }^{10}$ Since the reticulocndothelial system plays a iole in $\gamma$-globulin production, ${ }^{n, 14}$ the increase in $\gamma$-globulin synthesis, as scen in the present stully, most iikely arises from the reticuloendotholial system. This is supported by the following studies by others.

Bjo neboc has shown an intense prolifera. tion of plasma cells in the splecn of rabbits challenged with bacterial and foreign protein ar.tigens. These proliferative changes were currelatel with increases in serum globulin which led to the conclusion that plasma cells produced rost antibodies. ${ }^{2}$ A strikingrly similar plasma cell and lymphocytic proliferaticn was noted in many organs following total homotransplantation of the dog liver." These authors concluded that the reticuloendothclial system was stimulated by the homograft rejection mechanism. ${ }^{11}$ Additional evider ce is found in homograft prolongation studies such as the one by Zukoski and assir. cintes. ${ }^{10}$ These workers showed that an $i n$. difed absence of the germinal centers of the mphatic syenen bessencl the intensity of the bemograti rejection mechaisism and pro. inged survival of the inomutransiatia ef kitucy. The germinal centers of the lympin rume and spleen aie the source of the merliwin- and smali-sized lymphocytes. Wissler (i)i) associates state in a recent review that Anese ceis along witin the plasma celis are perhaps the main cells producing antihody groutilin. ${ }^{14}$ 'Thus, it is apparent that ceils of the reticulocindiothelial system that produce $\gamma$-globulin antibody are also prominent in the role of homograft rejection. It is reason. able to assume that increased $\gamma$-giobuiin synthesis seen after liver transplant is caused by stimulation of the reticubendotheliai sysiom as a result of homegraft rejection. Moore and associates in their stiribes afier liver tmansplant reponted no increse in 7 yobulin levels as measured by pafer eiec hophonesis andyos. ${ }^{10}$ Increases in synthesis rates, bowever, may not always be detecied by changes in the concentration of any given protein.
Miriti:M

The inc mucriprote is most lif inflammat, the hromog: Fowler, at homotran: was the or elevated. were only showed a which mas genic stim one-tenth 1 The incre: plants was co-worker: crease in authors a mucoprote a result of since the experimen Winzler, i that muco forms of sintree of kiecent wor of the me iiver.

Since th an! filerine prenented Tiver capab formation . mals, there as compare fibrinogen. represeni a transplante of heratic pheted duri mal is witl icinsplant scii, in par: turiover, $\mathrm{i}$ to acuite de regritr and silerable n such as hor

Kiskral et al.

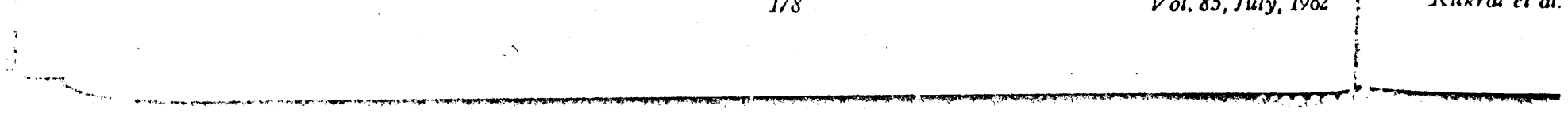


allitisia hiblibitis. in jhils it Q Hition la juctat - reticalis. id 6 me

polition. ol rabbits nepotion is $11 \mathrm{cos}$ : sobulin asmin colls stikingly proitionafollowing "liver." retictiod ly in Aribinatio indinat and assor ait an $\quad$ iners of inc Siyot tise ani proneplanted ine ivimh tion $n$ be

livsior ris.. tita! cail an הation, ta cols provine aidian ia 5 mastiamitia ? ?t: is c....... icinat rejection. lico atur rense: rea ciecs.mans detents

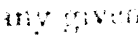
$, J 61 y, 1902$

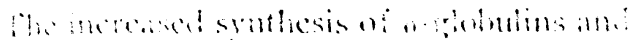

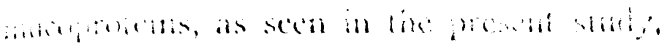
is ahes haty on the hasis of a momspecinc

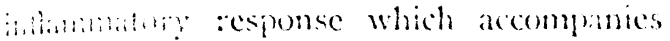

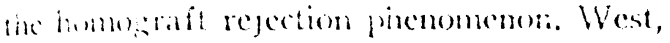
linwier, and Nathan in their work wa remat

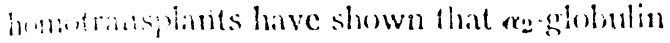
Wi: the ony ghobulin which was consistently cievated. Increases in $\beta$ - and $\gamma$-grlobulins were only inconsistentiy noted. ${ }^{12}$ Our stucy showed a scueral increase in all globulims which may be related to the size of the antisemic stimulus, since the kirlney is about une-tent's the size of the normal liver in dogs.

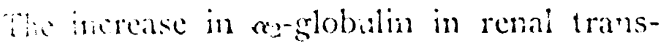
hims was further investigated by West and a-wotkers and found to be due to an incrove in the mucoproten fracion. These anthors concludich that increas in serum

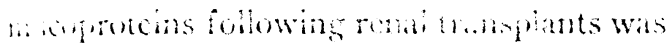

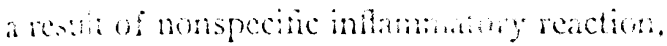

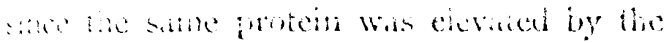

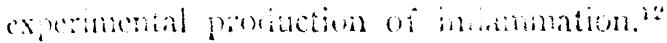

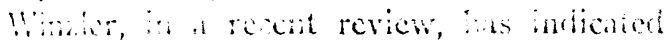

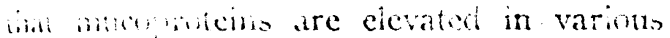
boms of ahammation, althoust the exate sure of these proteins is still misctied. ${ }^{13}$

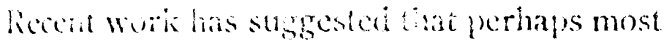

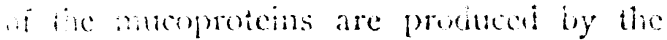
$\operatorname{mat}$

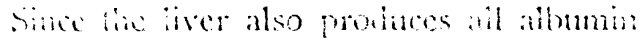

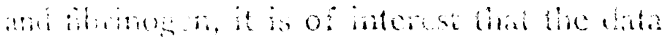

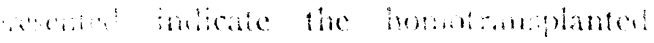

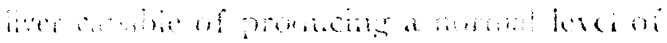

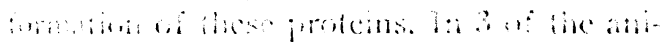

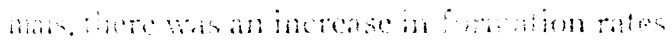

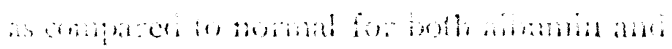

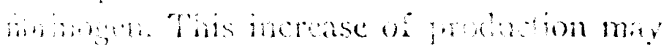

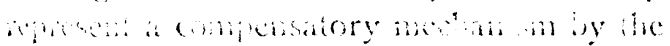

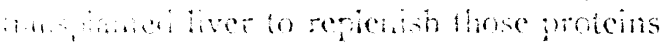

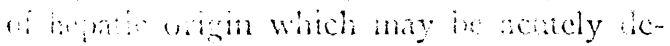

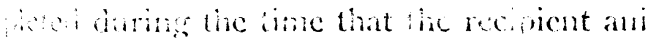

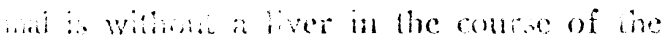

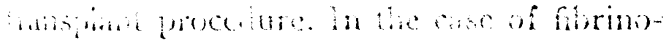

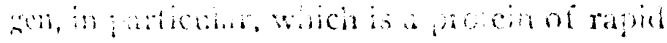

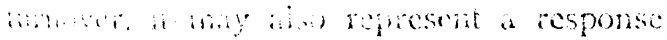

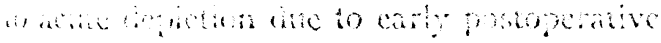

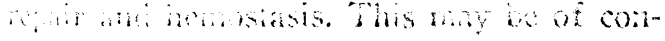

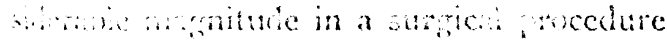

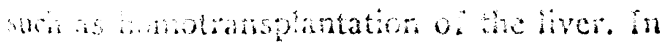

aniratial.

\section{8}

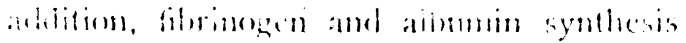

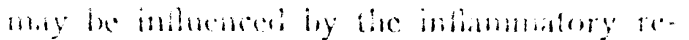
rinnse allewding homogralt iejection. This

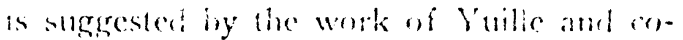
wortiers, ${ }^{10}$ who showed an increased syntice sis and turmover of allomin and, cspecially, fibinogen after experimentally induced absceises in rogs. In spite oi the marked variations in plasma protein synthesis noted, the concentrations of these protcins as determined by routine laboratory methods showed n) change except terminally (Fig. 5). This is rerhips explained by the fact that total protein and albumin levels do not reflect acute metabolic changes witil late.

$Y i$ is apparent that the plasma protein patteria following total homotransplantation of the liver shows a change from anrmal. Gen. Malacel increases in ghobulin symtiesis, espe-

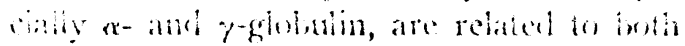
andepectic and specife phases of the lumb-

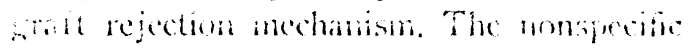

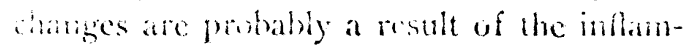
minory response secondary to the rejecion mechanism and are refected primarily as increases in the mucoprotein fraction. Albumin and hbrinogen synthesis may also be reated to the secondary inflammatory changes $a$ in acute depletion in the conses of the fansplant procentare. further investation

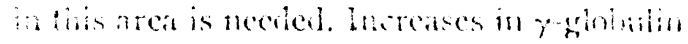

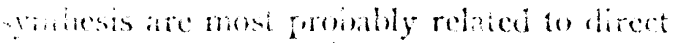

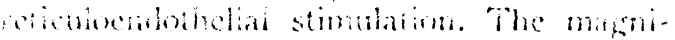
sate of this response is pathably relater to

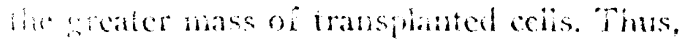
the Aver, one of the brgest organs which can he handanted crolkes the most intense response.

\section{Conclusions}

Cian,es in finsma protein synthesis were

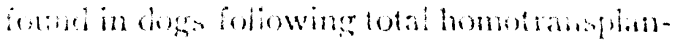

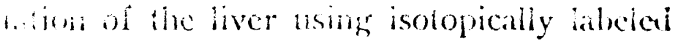
ami1', acids to defermine formation rales. Oine changes are most ikciy reiated th a

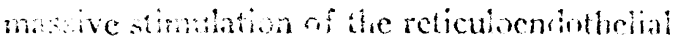
asen by the rejection of a harge organ such an hio liver.

nacreases in the globulins were most con-

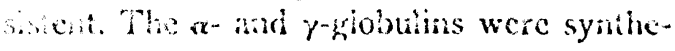


sied fwic as bist afier liver transplant as in the awimal dors.

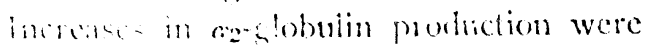
Chane to merased symhesis of macopro-

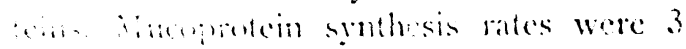

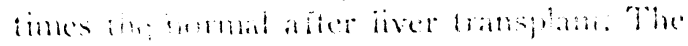

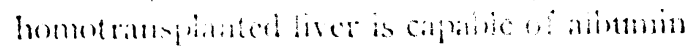
and tiondosen synthesis on the fourth day atior transwant.

A pospessive distructive jandice is noted in the dog following live tansplantafion as jus sed iny routine liver tunction tests.

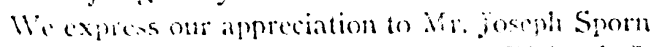
for cishical assistance and to Dr. Richard $j$. Winzier for guidiune in the mucoprotcin analyses.

Johu C. Kukral, M.D., 333 iiast Huron, Chicago 11, III.

\section{RENERENCES}

1. Armstrong, S. M., Tr.; McLcod, K.; Volter, I. and Kinral, J.: The Persistence in the Biod of K... Giobulins of Intermeliate Mohility Struied wit: $S^{*}$ and Paper Fiectrophoresis: Merhots and Prelimmay Reswits, J. L . h. Clin. Med. 43:918-037, 19.74.

2. Bionchos, M. and Gomen, H.: Experi-

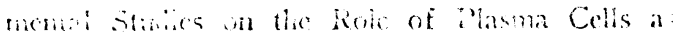

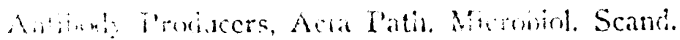
$21,1,19+3$.

i. A H Herga, I.; Dubin, A.; Kramer. D. S.;

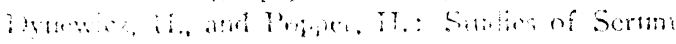

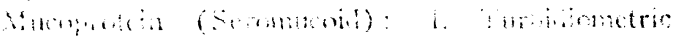

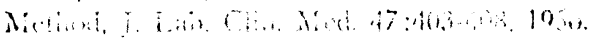

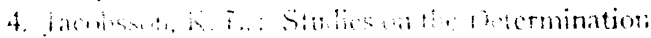

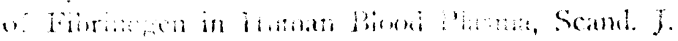

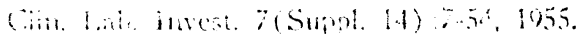

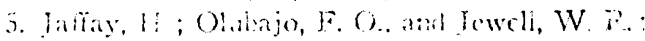
Buterianation of Kadioactive Sibin in Biological Matcrals, Anal. Chem. 32:306-308, 1960.

6. Kukrai, I. C.; Kerth, J. D.: Pancuer, R. J.; Cromer, 1). WV., and IIcnerar, G. C.: P'asmai

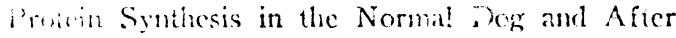
Totil infaticetomy, Surg. Gynec. Obsict. 113:360 $37 \therefore, i \% 6:$.

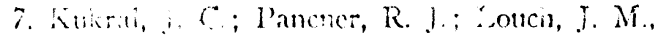

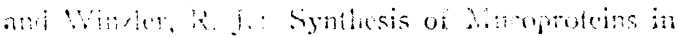

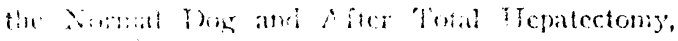

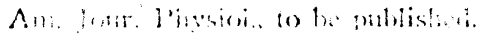

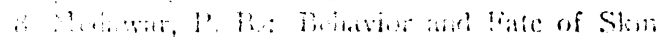

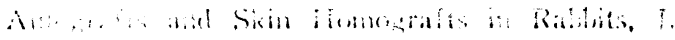

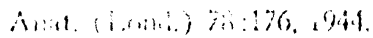

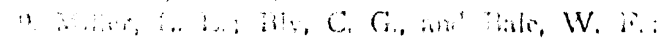

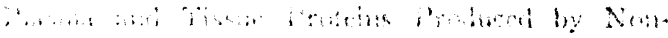

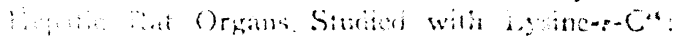

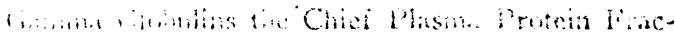

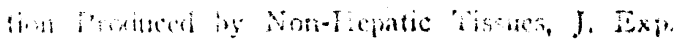

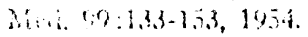

10. Monre He 1), Whecter. H. H.; Hemissianes, 11. V.; Smith, I. Y., Hallankura, O); AhI, K.; Crectilere, J. H., and i):mmin, l; J. : Experimental Whole () rean Tramsplantalion of the liver and of Hue Siplen, Amn. Sirre 152:374, 1900.

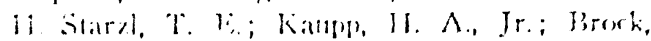

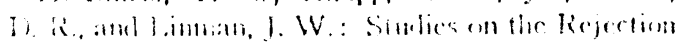
of the Transolanted Homolegens Joge River, Surse

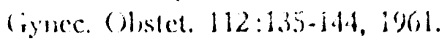

2. West, C. i).; Jinwler, R., Ir, and Nathan, P.:

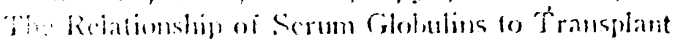

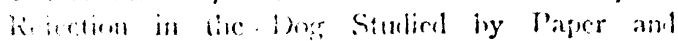
Imbinoclectrophoretic ت̈chnigucs, Anm. N.Y. Acill. Sci. $87: 522-537,1960$.

13. Winzler, R. I.: Determinations of Serim Elocoprotcins, in Gilk, D) : Metherls of Binciemical Analysis, New York, Interscience Publishers, Inc., i 955, Voi. 2, p. 279.

i4. Wissler, R. W/.; Fitch, F. W., and La Via, M. F.: The Reticuloendothelial System in Antibely Inrmation, Ann. N.Y. Acarl. Sci. 88:134-148, 1960.

15. Yuille, C. L.; 'ucas, F. V.; Jones, C. K.; Chapin, S. I., and Whipple, G. H.: Inflammation anci Protein Metabclism Studies of Carbon-14Labelled Proteins in i)gs with Sterile Abscesses, J. Bxp. Med. $98: 173-194,1953$.

16. Zukoski, C. F.; I,ce, H. M., and Hume, D. M.: The Effect of 6-Mercaptopurine on kenal Itomograft Survival in the Dog, Surg. Gyner. Oistet. $113: 707-714,1961$.

\section{DISCUSSION}

Dr. Franihtck W. Preston, Chicago: Transantation of Bivers bino iveriess doge with sintSyent survival of the animals for more than 2 weths (one of the deres which this protip studich sarvived 3 weeks) is a noteworthy achicrencent an! repic ents a contribution to the science of imo. irausplantation.

i)r. Kukral and otices have shown that animals with homotransplanted livers are able to carry on most of the futctions ascribed to the liver, but the report of Dr. Kukral which you have just heari pacsents the first ictailal study of the piasma prolin fractions in the animal with liver homotransplant.

Since some of the animals lived for more than? wers, one might assume that the homotranspinte.

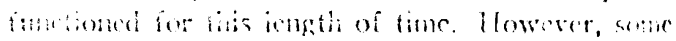

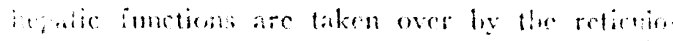

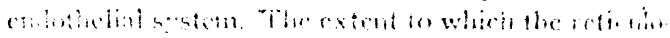

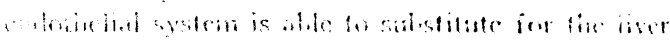

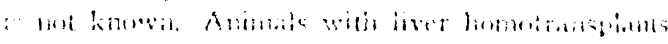

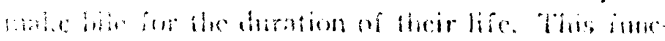

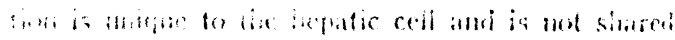

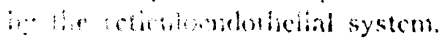

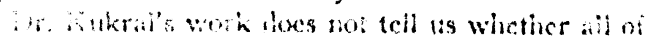

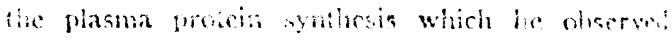
Went on tat the liver or whether the source of some it these proteins might be the retictioembotichit syrimen. $\wedge$ tot biene tiran 3 , lirsurs or les hypeifigermiat. crimillelial sys of ingutic fun

lii bien hrom Bathicit asoun retirulesendesthe. werk, and it i.

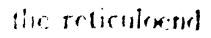
Icristic of surs.

On the oshe: aiso has an of aminatis irrliv for the reject reticulocnolothe as 6-mercapte nephrectomizer 


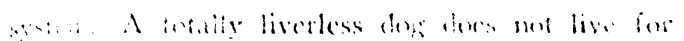

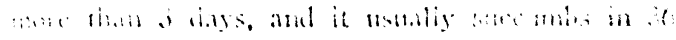

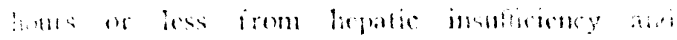

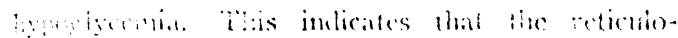

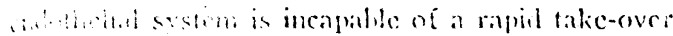

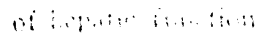

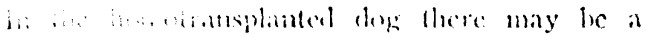

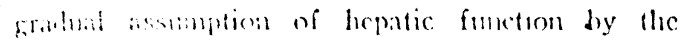
rewaluenthelial system over a period of days or wohe, and is is inceresting to speculate as to whether

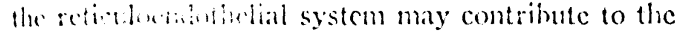
brath of surviat of the liverless anmal.

(i) He ofler hatin, the retionlocndothelial system aks bas an whosite effect, in that it proteds the

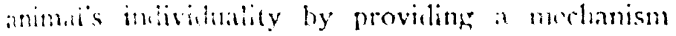
for :he rejection of Womo rafts. Datakging the

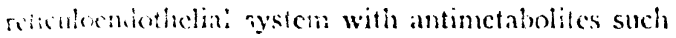
$\therefore$ inncrophomurine has make it pessible for atroctomiacd dogs to live for as $\mathrm{long}$ at 3 montins

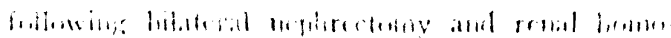

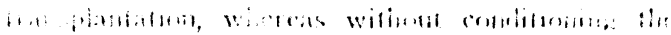

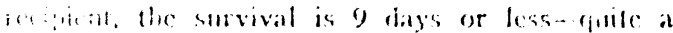
ditientire.

Sertaning ome of the next steps in the field of liver bemongunsplantation will consern motheres of conditioning the recipicut. In our laleratory we firave fomml that cyfoxan is superior to a variely of other alkalating agents and antimetabolites in conditioning mice for homotransplants of skin. The homografls live about twice as bong in conditioner as in control animals.

Staral used total-borly irradiation in an cffort to prolong the life of sone of these animals with liver triusplants, hut much less progress has been mace in contitioning animals for hepatic than for ronal homotransplants. Conditioning the recipient of a fomograte may provide the key for permanent succoss if homografts, thus making it possible to curc discase by organ replacement. so: Transs with suinors: th, n 2 rowi sinici ievement and ce of homo-

Awa mimisis (1) aloy (i) he Here, int we inst in ari

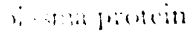
mantatsplata. andere that 2 amsia spints low rer, stme tine retionseh Her retarists. - Fe. Min: ine: molrambilinds ir. Mto ano tis an tharel

wh be all h in: cimerved sore te ot setsin irn thentivet 1. 85, J5/3. 2902 